\title{
Validation of the Comply with Post-Exposure Management Among Health Care Workers Instrument for Brazil*
}

\author{
Validação para o Brasil do Comply with Post-Exposure Management Among Health Care Workers \\ Validación para Brasil del Comply with Post-Exposure Management Among Health Care Workers
}

Adriane Corrêa Jansen¹, Maria Helena Palucci Marziale², Cláudia Benedita dos Santos ${ }^{3}$, Rosana Aparecida Spadotti Dantas $^{2}$, Danielle Maria de Souza Serio dos Santos ${ }^{4}$

How to cite this article:

Jansen AC, Marziale MHP, Santos CB, Dantas RAS, Santos DMSS. Validation of the Comply with Post-Exposure Management Among Health Care Workers Instrument for Brazil. Rev Esc Enferm USP. 2016;50(6):971-979. DOI: http://dx.doi.org/10.1590/S0080-623420160000700014

* Extracted from the thesis "Adaptação cultural e validação para o Brasil do instrumento Comply with post-exposure management among health care workers para profissionais de enfermagem", Programa Interunidades de Doutoramento em Enfermagem, Escola de Enfermagem de Ribeirão Preto, Universidade de São Paulo, 2014

${ }^{1}$ Universidade Federal de Uberlândia, Escola Técnica de Saúde, Uberlândia, MG, Brazil.

${ }^{2}$ Universidade de São Paulo, Escola de Enfermagem de Ribeirão Preto, Departamento de Enfermagem Geral e Especializada, Ribeirão Preto, SP, Brazil.

${ }^{3}$ Universidade de São Paulo, Escola de Enfermagem de Ribeirão Preto, Departamento de Enfermagem Materno-Infantil e Saúde Pública, Ribeirão Preto, SP, Brazil.

${ }^{4}$ Universidade Federal do Rio de Janeiro, Curso de Farmácia, Campus Macaé, Macaé, RJ, Brazil.

\section{ABSTRACT}

Objective: To validate the Comply with post-exposure management among health care workers instrument for Nursing in Brazil. Method: A methodological study carried out with 137 nursing professionals exposed to biological material. The existence of floor and ceiling effects was analyzed, evaluating reliability by the internal consistency of the items and test-retest reproducibility. The construct validity was analyzed by the multitraitmultimethod analysis. Results: Ceiling effects were found in two subscales. The result of the internal consistency of four subscales varied between 0.81 and 0.91 . The results were considered satisfactory, while two subscales presented an unsatisfactory result $(0.50$ and 0.37 ). An evaluation of the measurement stability obtained positive results in relation to the statistical significance, with Intraclass Correlation Coefficient values between the two measurements ranging from 0.301 to 0.727 ; the validity of a convergent and divergent construct was confirmed by multitrait-multimethod analysis, except for the Attitude subscale, which presented unsatisfactory values. Conclusion: The instrument presents satisfactory results for validity and reliability, except for the Attitude dimension.

\section{DESCRIPTORS}

Exposure to Biological Agents; Nursing; Intention; Occupational Health; Validation Studies.
Corresponding Author:

Adriane Corrêa Jansen

Av. Prof. José Inácio de Souza, s/n. Bloco 6X

$1^{\circ}$ Andar - Campus Umuarama

CEP 38400-902 - Uberlândia, MG, Brazil

adriane.jansen@ufu.br
Received: 05/30/2016

Approved: 11/16/2016 


\section{INTRODUCTION}

Safety and health at work represents a challenge for governments and organizations, considering the social and economic costs resulting from occupational accidents and occupational illnesses, so the prevention of occupational risks is a constant concern that has deserved attention.

Despite the obligation related to using standard precautions and specific control and prevention legislation, accidents involving exposure to biological materials continue to be registered, perpetuating the serious problem of occupational hazards in the hospital environment ${ }^{(1-2)}$.

Frequent handling of piercing material by health professionals, coupled with factors such as professional inexperience, inadequate working conditions, absence or inadequacy of protective equipment, physical and mental fatigue and the need for great agility in performing activities contribute to increased accident risk involving exposure to biological material ${ }^{(3)}$.

The reality of exposure to accidents involving biological material among health professionals, and especially for nursing, can be confirmed by the numerous published national and international studies. This worrying scenario is even more serious in view of the fact that adherence to postexposure behavior among health professionals is still not satisfactory, especially in developing countries ${ }^{(4-9)}$.

Through a broad search in the national and international databases to identify valid and reliable instruments that quantify occupational post-exposure behavior, as in another Brazilian study ${ }^{(10)}$, we found that there are no validated instruments available in Brazil to assess the risks of exposure to biological material or the impact of prevention and control measures, nor to evaluate the knowledge, attitudes and practices of health professionals in relation to this type of exposure.

One instrument was identified at international level ${ }^{(11)}$, based on the theoretical framework of the Theory of Planned Behavior (TPB), to predict the intention of health professionals accidentally exposed to blood and body fluids in complying with conduct related to post-occupational exposure and in describing the exposure circumstances and the professionals' adherence to the recommended conduct. The instrument was submitted to face and content validation and to the reliability test, which evaluated its internal consistency using Cronbach's alpha (with indices between 0.60 and 0.95).

This instrument was originally developed in Chinese （健康照顧專業人員職業性危害針扎後之追蹤）and was translated by English authors as Comply with post-exposure management among health care workers ${ }^{(11)}$. It was translated and adapted for use in Brazil in Brazilian Portuguese, entitled Adesão às condutas pós-exposição entre trabalbadores de saúde $(A C P E T S)^{(12)}$.

The objective of the present study was to validate the instrument Comply with post-exposure management among health care workers for nursing professionals in Brazil.

Selecting an instrument from another linguistic origin in the present study is justified by the international potential for cooperation in the area of Occupational Health, with the purpose of increasing scientific knowledge toward prevention of occupational exposure to potentially contaminated biological material and promoting occupational health; also, to strengthen ties and exchanges among different countries where problems of occupational exposure are experienced.

\section{METHOD}

A methodological quantitative study with data collected from six general hospitals of the city of Uberlândia, Minas Gerais, Brazil. The target population of the study consisted of 156 nursing technicians and 32 nurses working in these hospitals and who had experienced a work accident with biological material in the period of 2010 to 2012 . Nursing technicians and nurses of both genders who were actively working during the data collection period and those who agreed to respond to the data collection instrument were included in the study. Nursing technicians and nurses who were on vacation, health leave, dismissal from work, those who had been dismissed and the professionals who participated in the translation and adaptation stages of the ACPETS tool were excluded from the study ${ }^{(12)}$. Thus, the study sample consisted of 137 nursing workers, 119 nursing technicians and 18 nurses. Data collection was performed from November, 2012 to February, 2013, using the ACPETS tool.

It is a self-administered instrument composed of three parts: two parts presenting objective and subjective sequential questions related to personal and professional characterization data of the study subject (Basic data) and characterization of the last occupational exposure occurred (Exposure to occupational risk of biological material); and a third part with 61 items containing Likert scale response options, where dimensions related to TPB constructs are presented (Attitude, Subjective norms, Perceived behavioral control and Intention).

The Attitude dimension is composed of 12 items with five answer options (I completely disagree, I disagree, no opinion, I agree and I completely agree) ranging from one to five. It refers to the attitude of health professionals when exposed to occupational risks and is defined as the degree of positive or negative assessment related to compliance with post-exposure behaviors ${ }^{(11)}$. Average Attitude is obtained by summing the values of the answers to the scale items after recoding the three reverse items. The highest value for the score indicates a higher level of positive evaluation related to compliance with post-exposure behavior. After the initial analysis of the ACPETS tool, which highlighted that the Attitude subscale presented unsatisfactory results in the psychometric analyses, three items $(1.8,1.10$ and 1.11$)$ were considered as having a reverse score.

The Subjective norms dimension consists of 16 items with five response options (I completely disagree, I disagree, no opinion, I agree and I completely agree), ranging from one to five. This dimension indicates the professionals' perception of social pressure to comply with post-exposure behaviors. The items take into account expectations of significant people for professionals - parents, siblings, spouses or a significant other and supervisor - and their motivation to meet those expectations ${ }^{(11)}$. 
The third dimension, Perceived behavioral control, is defined by the authors ${ }^{(11)}$ as the perception of professionals relating to the difficulty or ease with which the post-exposure conducts can be performed. This dimension is measured through three subscales: Knowledge, Self-efficacy and Resources.

The subscale Knowledge has 13 items with three answer options (Yes, No, I do not know), to which the authors ${ }^{(11)}$ attributed a value of one (1) for the option Yes and a value of zero (0) for the options No and I don't know for data analysis, leading to a dichotomous response format. A strategy for dealing with dichotomous items is grouping items in order to generate scores (called plot items) from the sums of two or more similar items ${ }^{(13)}$. Thus, in order to perform the multitrait-multimethod analysis, the Knowledge subscale was grouped by taking into account the similarities in the items' content. The subscale was subdivided into three plot items, as follows: E3.1 - group with content related to conduct after exposure to biological material (items 3.3, 3.5, 3.7, 3.8, 3.10); E3.2 - group with content related to the use of medication (items 3.2, 3.4, 3.13); E3.3 - group related to other content (items 3.1, 3.6, 3.9, 3.11, 3.12). In this subscale, the higher the score value, the greater the professional's knowledge about post-exposure behaviors.

The Self-efficacy subscale has seven items with five answer choices (I'm very insecure, I'm insecure, no opinion, I'm sure, I'm very sure), ranging from one to five. Higher scores indicate greater perception of self-efficacy ${ }^{(11)}$. Regarding the Resources subscale, it consists of six items with five response options (very dissatisfied, dissatisfied, no opinion, satisfied, very satisfied) ranging from one to five. The highest value for the score indicates greater satisfaction with the institutional resources related to occupational exposures to biological material ${ }^{(11)}$.

The Intention dimension has seven items, with five response options (I don't have any intention, I have no intention, no opinion, I have the intention, I do have the intention). According to the authors ${ }^{(11)}$, it refers to the professional's intention to comply with the occupational post-exposure conduct, defined as the intention to report future injuries, to participate in counseling, to receive vaccination and postexposure prophylaxis and to return for final follow-up serology tests. The response options range from one to five, with the highest scores indicating greater intention to comply with the recommended post-exposure conduct after occupational accidents in the future.

For text uniformity of the present study and to facilitate description and analysis of the results, all dimensions of the instrument and its subdivisions were denominated as subscales of the instrument (Attitude, Subjective norms, Knowledge, Self-efficacy, Resources and Intention).

After elaborating numerical coding for all the answers, the data were stored in the Excel program (version 2010) using the double-entry validation (typing) technique, in order to diagnose and eliminate possible typing errors. After checking and correcting any inconsistently typed data in both digits, the data was then transferred to the SPSS application, version 17 (version 22.0, serial number 10101151049) to be processed and analyzed.
The response distribution to the instrument was described, and existence of the floor and ceiling effects were verified, considered to be present when more than $15 \%$ of the participating subjects choose the option corresponding to the lowest or highest possible score for each of the measuring instrument dimensions, respectively ${ }^{(14)}$.

The ACPETS tool's reliability was verified by the internal consistency of the items, with polytomous and dichotomous responses analyzed by Cronbach's alpha coefficient and Kuder-Richardson coefficient, respectively. Reliability evaluation by evaluating the measurement stability was also calculated by test-retest, with correlation analyses between the results obtained by applying the same measurement instrument in the same subjects on two different occasions, using the Intraclass Correlation Coefficient (ICC), and being classified as poor $(<0.40)$, fair $(0.41-0.60)$, good (0.61-0.80) or excellent $(>0.80)^{(15)}$.

In order to perform this analysis, the total of 30 professionals (with a loss calculation of $15 \%$ ) was defined, and thus the test-retest sample would consist of 36 subjects (18 nurses and 18 nursing technicians). These professionals were defined by random draw before the beginning of data collection of the study. After returning the completed instruments, participants were invited to participate in the second stage (retest), after clarifying its objectives and determining an interval of 30 days between the first and second participation. All subjects were invited and accepted, with the exception of four professionals who were on leave (two nursing technicians and two inactive nurses) and one nurse who had already refused participation in the study. Thus, the sample for the test-retest consisted of 31 professionals (16 nursing technicians and 15 nurses).

An interval of 30 days between the first collection (test) and the second measure (retest) was stipulated, taking into account that this time would allow for a decrease or elimination in the memory effect (related to remembering the answers given in the subject's first participation), and that there would be no probable modifications related to the constructs in the instrument. Thus, the chances of the participant being selected for the second collection (retest) and being absent due to holidays would be reduced if the stipulated time was shorter.

Multitrait-multimethod analysis (MTMM) was used to evaluate the validity of the convergent and divergent construct of the instrument through correlations between the items and the dimensions/subscales. The Multitrait Analysis Program (MAP) was used ${ }^{(16)}$ in order to carry out this analysis.

The linear correlations between items and dimensions/ subscales they belong to were verified for estimating the convergent construct validity. In final validation studies, acceptable correlation values for the convergent validity are greater than $0.40^{(17)}$. The divergent construct validity was estimated by checking the percentage of times in which the linear correlation between a given item with a dimension to which it hypothetically belongs was higher or statistically higher than its correlation with a dimension to which it does not belong ${ }^{(17)}$. 
The level of significance adopted in this study was $0.05(\alpha=0.05)$.

The Subjective norms subscale has a characteristic that favored the appearance of no response (missing data) on some items, such as those containing statements that were sometimes not applicable to certain subjects. Therefore, in the majority of analyses referring to this dimension (i.e. in the descriptive analyses, in MTMM analyses and Cronbach's alpha for estimating the internal consistency of the items), only the valid items (meaning those items for which all 94 participants responded) were considered. For the other scales, the 137 subjects were considered (Attitude, Knowledge, Self-efficacy, Resources, and Intention).

The Resources subscale had an item with missing data, whose value was overridden by the average of the items that make up the subscale of the respective subject. The item was deleted when a participant did not complete $20 \%$ or more of the answers.

The study received approval from the Ethics Committee for research with Human Beings of the Universidade Federal de Uberlândia, according to Approval Protocol 041/12. The name of the instrument contained in the title of this research project, informed in this opinion, is different from the name of the instrument used in this study because it was modified during the translation and cultural adaptation steps ${ }^{(12)}$. The participants read and signed the Free and Informed Consent Form, guaranteeing free and voluntary participation of the study subjects, as well as anonymity and confidentiality of the collected information.

\section{RESULTS}

The study sample $(\mathrm{n}=137)$ consisted of $119(86.9 \%)$ nursing technicians and $18(13.1 \%)$ nurses who presented the following characteristics: 120 (87.6\%) female participants, 72 (52.6\%) had technical education, 62 (45.3\%) were married and $51(37.2 \%)$ were single, aged between 19 and 58 years and mean age was 34.5 years ( $\mathrm{sd}=8.7$ ), with a median of 33.0 .

Regarding the distribution of the answers of the items for each subscale, floor and ceiling effects were not identified in the subscales of the ACPETS tool, except for the Self-efficacy and Intention subscales, which presented ceiling effect. The highest percentage value was found in the Intention subscale (39.4\%).

Internal consistency analysis of the items integrating the instrument was verified through Cronbach's alpha statistic (Attitude, Subjective norms, Self-efficacy, Resources and Intention subscales) and by the Kuder-Richardson coefficient (Knowledge subscale), according to Table 1.

Table 1 - Reliability analysis for the internal consistency of the ACPETS tool items' subscales - Uberlândia, MG, Brazil, 2014

\begin{tabular}{lccc}
\hline & Number of items & Cronbach's alpha & Kuder-Richardson Coefficient \\
\hline Attitude & 12 & $0.50^{*}$ & - \\
Subjective norms** & 16 & 0.89 & - \\
Perceived behavioral control & & & 0.37 \\
$\quad$ Knowledge & 13 & - & - \\
$\quad$ Self-efficacy & 7 & 0.91 & - \\
$\quad$ Resources** & 6 & 0.81 & - \\
$\quad$ Intention & 7 & 0.90 & \\
\hline
\end{tabular}

(*)Values obtained after the recoding of three items $(1.8,1.10$ and 1.11)

${ }^{(* *)}$ Values are based on the sum of the scores of valid items $(n=94) ;(* *) n=136$.

The reliability analysis of the instrument was also verified through test-retest reproducibility, considering its application in 31 members of the study sample at two distinct moments, with a 30 -day interval. ICC values of each subscale and the respective values of statistical significance are presented in Table 2.

Pearson's linear correlation coefficient values were calculated by the MTMM analysis between the items of the instrument and each of its subscales for analysis of the convergent construct validity, as described in Table 3 .

Table 2 - Reliability analysis of the ACPETS tool through test-retest reproducibility - Uberlândia, MG, Brazil, 2014.

\begin{tabular}{lcc}
\hline Subscale & ICC & $\boldsymbol{p}$ \\
\hline Attitude & 0.327 & $0.037^{*}$ \\
Subjective norms & 0.542 & $0.004^{* *}$ \\
Perceived behavioral control & & $0.001^{* *}$ \\
$\quad$ Knowledge & 0.504 & $0.000^{* *}$ \\
$\quad$ Self-efficacy & 0.727 & $0.016^{*}$ \\
$\quad$ Resources & 0.382 & $0.049^{*}$ \\
Intention & 0.301 & \\
\hline
\end{tabular}

(*) $0.01<\mathrm{p}<0.05$

$(* *) \mathrm{p}<0.01(\mathrm{n}=31)$. 
Table 3 - Pearson's linear correlation coefficient between the items and the six subscales of the ACPETS tool obtained by MTMM Uberlândia, MG, Brazil, 2014 analysis.

\begin{tabular}{|c|c|c|c|c|c|c|c|}
\hline & Item & Attitude & $\begin{array}{c}\text { Subjective } \\
\text { norms }\end{array}$ & Knowledge* & Self-efficacy & Resources & Intention \\
\hline \multirow{12}{*}{ 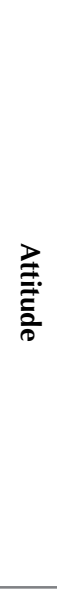 } & 1.1 & 0.32 & 0.09 & -0.04 & 0.07 & 0.00 & 0.05 \\
\hline & 1.2 & 0.20 & -0.07 & -0.19 & -0.11 & -0.14 & -0.07 \\
\hline & 1.3 & 0.24 & 0.18 & 0.07 & 0.15 & 0.04 & 0.10 \\
\hline & 1.4 & 0.08 & 0.00 & -0.15 & -0.08 & -0.14 & -0.19 \\
\hline & 1.5 & 0.20 & 0.26 & 0.04 & 0.08 & 0.09 & 0.04 \\
\hline & 1.6 & 0.24 & 0.35 & 0.03 & 0.04 & -0.03 & 0.25 \\
\hline & 1.7 & 0.28 & 0.23 & 0.07 & 0.10 & 0.09 & 0.13 \\
\hline & 1.8 & 0.28 & -0.04 & -0.01 & -0.14 & 0.00 & 0.00 \\
\hline & 1.9 & 0.10 & 0.14 & 0.06 & 0.19 & 0.14 & 0.17 \\
\hline & 1.10 & 0.08 & -0.12 & -0.08 & -0.20 & -0.06 & -0.06 \\
\hline & 1.11 & 0.09 & 0.03 & -0.20 & -0.15 & -0.07 & -0.17 \\
\hline & 1.12 & 0.18 & 0.22 & 0.06 & 0.01 & -0.07 & 0.10 \\
\hline \multirow{16}{*}{ 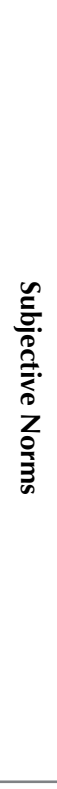 } & 2.1 & 0.21 & 0.50 & 0.12 & 0.16 & 0.20 & 0.33 \\
\hline & 2.2 & 0.27 & 0.67 & 0.06 & 0.23 & 0.10 & 0.17 \\
\hline & 2.3 & 0.24 & 0.62 & 0.06 & 0.18 & 0.14 & 0.27 \\
\hline & 2.4 & 0.19 & 0.56 & 0.11 & 0.19 & 0.18 & 0.07 \\
\hline & 2.5 & 0.17 & 0.63 & 0.09 & 0.21 & 0.20 & 0.24 \\
\hline & 2.6 & 0.18 & 0.68 & 0.06 & 0.15 & 0.15 & 0.25 \\
\hline & 2.7 & 0.23 & 0.68 & 0.08 & 0.20 & 0.22 & 0.21 \\
\hline & 2.8 & 0.07 & 0.47 & 0.02 & 0.11 & 0.15 & 0.06 \\
\hline & 2.9 & 0.32 & 0.79 & 0.18 & 0.26 & 0.06 & 0.24 \\
\hline & 2.10 & 0.29 & 0.75 & 0.09 & 0.22 & 0.07 & 0.22 \\
\hline & 2.11 & 0.23 & 0.76 & 0.11 & 0.23 & 0.04 & 0.16 \\
\hline & 2.12 & 0.12 & 0.52 & 0.05 & 0.11 & 0.10 & -0.02 \\
\hline & 2.13 & 0.25 & 0.57 & 0.20 & 0.33 & 0.16 & 0.07 \\
\hline & 2.14 & 0.31 & 0.60 & 0.06 & 0.26 & 0.12 & 0.06 \\
\hline & 2.15 & 0.27 & 0.56 & 0.18 & 0.31 & 0.15 & 0.02 \\
\hline & 2.16 & 0.21 & 0.43 & 0.14 & 0.20 & 0.20 & -0.02 \\
\hline \multirow{3}{*}{ 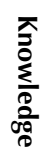 } & 3.1 & 0.00 & 0.13 & 0.64 & 0.54 & 0.23 & 0.21 \\
\hline & 3.2 & 0.10 & 0.19 & 0.81 & 0.67 & 0.32 & 0.23 \\
\hline & 3.3 & 0.02 & 0.07 & 0.72 & 0.65 & 0.19 & 0.25 \\
\hline \multirow{7}{*}{ 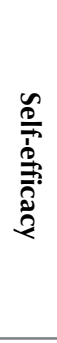 } & 4.1 & 0.05 & 0.18 & 0.72 & 0.66 & 0.26 & 0.17 \\
\hline & 4.2 & 0.15 & 0.25 & 0.70 & 0.67 & 0.33 & 0.28 \\
\hline & 4.3 & 0.14 & 0.28 & 0.56 & 0.57 & 0.31 & 0.30 \\
\hline & 4.4 & 0.15 & 0.38 & 0.59 & 0.52 & 0.22 & 0.22 \\
\hline & 4.5 & 0.16 & 0.18 & 0.33 & 0.46 & 0.43 & 0.01 \\
\hline & 4.6 & 0.25 & 0.20 & 0.24 & 0.44 & 0.51 & -0.07 \\
\hline & 4.7 & -0.03 & -0.03 & 0.13 & 0.20 & 0.40 & -0.16 \\
\hline \multirow{6}{*}{ 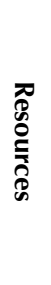 } & 5.1 & -0.06 & 0.02 & 0.19 & 0.38 & 0.48 & 0.08 \\
\hline & 5.2 & -0.02 & 0.14 & 0.22 & 0.43 & 0.45 & -0.05 \\
\hline & 5.3 & 0.09 & 0.05 & 0.04 & 0.37 & 0.39 & -0.14 \\
\hline & 5.4 & 0.05 & 0.29 & 0.25 & 0.25 & 0.26 & 0.41 \\
\hline & 5.5 & 0.04 & 0.22 & 0.29 & 0.28 & 0.29 & 0.44 \\
\hline & 5.6 & 0.01 & 0.20 & 0.14 & 0.18 & 0.31 & 0.40 \\
\hline
\end{tabular}




\begin{tabular}{|c|c|c|c|c|c|c|c|}
\hline & Item & Attitude & $\begin{array}{c}\text { Subjective } \\
\text { norms }\end{array}$ & Knowledge* & Self-efficacy & Resources & Intention \\
\hline \multirow{7}{*}{ 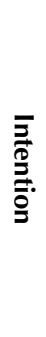 } & 6.1 & 0.09 & 0.24 & 0.24 & 0.18 & 0.24 & 0.57 \\
\hline & 6.2 & 0.07 & 0.19 & 0.37 & 0.28 & 0.23 & 0.58 \\
\hline & 6.3 & 0.05 & 0.19 & 0.36 & 0.26 & 0.25 & 0.59 \\
\hline & 6.4 & 0.01 & 0.16 & 0.40 & 0.25 & 0.27 & 0.60 \\
\hline & 6.5 & 0.05 & 0.02 & -0.19 & -0.09 & 0.07 & -0.19 \\
\hline & 6.6 & 0.20 & 0.12 & 0.17 & 0.02 & -0.02 & 0.24 \\
\hline & 6.7 & 0.14 & 0.00 & 0.00 & -0.03 & -0.05 & 0.12 \\
\hline
\end{tabular}

$(*)$ The values are grouped in "item plots", according to the description presented in the item Material and Methods.

For analysis of the divergent construct validity according to the MTMM analysis, the percentage of times when the linear correlation between an item with the subscale to which it belongs is greater or statistically greater than its linear correlation with a subscale to which it does not belong was verified and called "adjustment". To verify the validity of a divergent construct, we consider the concentration of the percentages obtained with the sum of values 1 and 2, meaning the items that present significantly larger correlations, or only larger correlations with their subscale than with other dimensions. Table 4 presents the values for the divergent construct analysis obtained by the MTMM.

Table 4 - Adjustment values resulting from the MTMM analysis for the ACPETS tool scores - Uberlândia, MG, Brazil, 2014

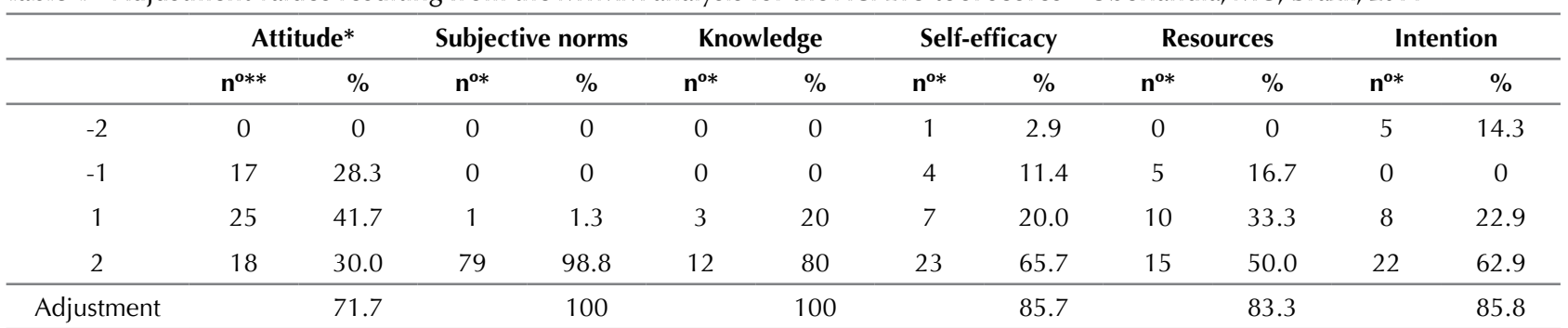

$\left({ }^{*}\right)$ Values obtained after recoding three items $(1.8,1.10$ and 1.11$)$.

(**) Number of comparisons made.

\section{DISCUSSION}

The sociodemographic characteristics of the participants in this study are similar to those of the nursing workforce in Brazil, as disclosed by the Federal Nursing Council $(\mathrm{COFEn})^{(18)}$, in which the majority of the professionals are female $(87.2 \%)$, single $(49.3 \%)$ or married $(34.6 \%)$, with a large number of subjects concentrated in the 26-35 age group (36.0\%) and from 36 to 45 years $(27.2 \%)$. It should be noted that similar results were also obtained in other studies ${ }^{(6,19)}$.

The predominance of technical level education is justified by the large number of professionals in this category $(52.6 \%)$ in the study. According to the data analyzed by the COFEn study ${ }^{(18)}$, the category of nursing technicians is the most prevalent among all professional nursing categories in all Brazilian geographic regions, accounting for $43.2 \%$ of the total number of nursing professionals in Brazil.

In a study that aimed to evaluate the conduct of nursing professionals who were exposed to biological material at a specialized hospital in the interior of São Paulo, $56.8 \%$ of the injured professionals had completed secondary education, $30.4 \%$ had completed post-secondary education and 8.4\% were attending post-secondary education ${ }^{(9)}$.

Concerning the results on the existence of floor and ceiling effects in each of the subscales in the present study, the ceiling effect was identified in the Self-efficacy (31.4\%) and in the Intention (39.4\%) subscales, contributing to a decrease in the instrument's responsiveness, as study participants who opted for the higher values in these two subscales may not be differentiated from each other, and changes over time may not be attributed to possible interventions, but rather to the presence of these effects. In addition, the presence of these effects indicates losses in the upper limits of these subscales, thus impairing the maintenance of the instrument's content validity.

No studies related to instrument validation in the area of worker's health were found which evaluated responsiveness through floor and ceiling effects. The presence of these effects was also verified in other instrument validation studies for Brazil ${ }^{(20-23)}$, using other thematic approaches related to the health area and carried out using patient or health professional samples.

The obtained Cronbach's alpha results indicated coefficients above 0.70 for most subscales, with the exception of the Attitude subscale (0.50). We highlight that 0.70 is the reference value for internal consistency ${ }^{(14)}$. The other subscales presented Cronbach's alpha values ranging from 0.81 to 0.91 , indicating good internal consistency of the subscale items. Regarding the Knowledge subscale, the obtained Kuder-Richardson coefficient was 0.37 , which is considered unsatisfactory.

Internal consistency results obtained in this study present higher values than those found by another study ${ }^{(24)}$, whose 
author states that even well-developed measures on attitude, subjective norms, perceived behavioral control and intention in relation to a behavior of interest rarely have reliability values higher than 0.75 or 0.80 .

The results obtained in verifying the instrument's testretest reproducibility were considered positive in relation to its statistical significance, since the agreement values between the two measures ranged from 0.301 to 0.727 , and three subscales presented weak agreement values, two moderate agreement values and one substantial agreement value ${ }^{(15)}$.

Considering that the assessment of an instrument's stability implies verifying similar responses in repeated measures performed with the same subjects ${ }^{(14)}$, we can infer that changes in the responses obtained for the subscales which presented low concordance values (Attitude, Resources and Intent) found in this study occurred due to the 30-day time interval adopted between the two collections, although higher values were also identified.

The main problem of reliability testing through the test-retest approach is that many traits of interest, such as attitudes, mood, and knowledge, can be modified by experiences between the two measures, regardless of instrument stability ${ }^{(25)}$.

The results of the divergent and convergent construct validity, verified by Pearson's linear coefficient according to the MTMM analysis, were expressive. The authors of the original instrument validation study did not perform this analysis.

In the convergent construct validity analysis through comparison of the linear correlations between an item and its subscale ${ }^{(17)}$, we found that the results were satisfactory for most subscales, except for the Attitude subscale (all items with lower values of 0.40), and some items of the Self-efficacy, Resources and Intention subscales. By grouping the items carried out in the Knowledge subscale, the convergent construct validity analysis was undertaken with 51 items; among these, coefficients were superior to 0.40 for 31 , corresponding to $60.8 \%$ of the instrument. Of the total items, only one presented a negative correlation value (6.5), indicating inconsistency between this item and its subscale.
For the divergent construct validity analysis, the comparison was made between the linear correlations between an item and the subscale to which it does not belong ${ }^{(17)}$. The percentages of items that showed higher correlations with their respective subscales and higher significance surpassed the correlations of these items with other subscales of the adapted instrument, indicating that the instrument distinguishes the subjects according to the scores in the dimensions involved in TPB. The best results for construct validity occurred for the Subjective Norms and Knowledge subscales with $100 \%$ adjustment, and four with adjustment values between 85.8 and $71.7 \%$.

Results close to those reported in this study have also been found in instrument validation studies which also used MTMM analysis on samples of chronic patients ${ }^{(21,26)}$.

The sample size can be considered a limitation of this study, which despite including all the eligible target population did not allow for accomplishing a confirmatory factorial analysis, which is necessary to verify its dimensionality.

\section{CONCLUSION}

The ACPETS tool presents satisfactory validity and reliability results, apart from the Attitude dimension, which presented unsatisfactory results from the performed psychometric analyses.

The approach to the theme 'behavior post-exposure to biological material', structured in the Theory of Planned Behavior and related to the methodological instrument validation process was only verified in the Chinese study that supported the present investigation and in some other investigations that partially addressed some of the related topics, as described throughout this research. Thus, in view of the incipience of the studies carried out regarding this topic, it was not possible to make more comparisons or more consistent analysis of the results. However, the instrument validated herein was adequate to the objective it proposes. The results obtained in this study offer new and important contributions to the areas of Nursing and Occupational Health, supporting future research with a focus on behavioral analysis, related to the intention to comply with internationally recommended post-exposure behavior.

\section{RESUMO}

Objetivo: Validar para o Brasil o instrumento Comply with post-exposure management among health care workers para a enfermagem. Método: Estudo metodológico realizado com 137 profissionais de enfermagem expostos a material biológico. Analisou-se a existência dos efeitos floor e ceiling e avaliou-se a fidedignidade pela consistência interna dos itens e estabilidade da medida (teste-reteste). Analisou-se a validade de construto por meio da análise multitraço-multimétodo. Resultados: Verificaram-se efeitos ceiling em duas subescalas. O resultado da consistência interna, de quatro subescalas, variou entre 0,81 e 0,91, resultados considerados satisfatórios, e duas subescalas apresentaram resultado insatisfatório $(0,50$ e 0,37$)$. A avaliação da estabilidade da medida obteve resultados positivos em relação à significância estatística, com valores do Coeficiente de Correlação Intraclasse, entre as duas medidas, variando de 0,301 a 0,727; confirmou-se a validade de construto convergente e divergente por meio da análise multitraço-multimétodo, exceto a subescala Atitude, que apresentou valores insatisfatórios. Conclusão: $\mathrm{O}$ instrumento apresenta resultados satisfatórios de validade e fidedignidade, excluindo-se a dimensão Atitude.

\section{DESCRITORES}

Exposição a Agentes Biológicos; Enfermagem; Intenção; Saúde do Trabalhador; Estudos de Validação. 
de los efectos floor y ceiling y se valoró la fidedignidad por la consistencia interna de los ítems y la estabilidad de la medida (test-retest). Se analizó la validez de constructo por medio del análisis multibrazo-multimétodo. Resultados: Se verificaron efectos ceiling en dos subescalas. El resultado de la consistencia interna, de cuatro subescalas, varió entre 0,81 y 0,91, resultados considerados satisfactorios, y dos subescalas presentaron resultado insatisfactorio $(0,50$ y 0,37$)$. La evaluación de la estabilidad de la medida obtuvo resultados positivos con relación a la significación estadística, con valores del Coeficiente de Correlación Intraclase, entre ambas medidas, variando de 0,301 a 0,727; se confirmó la validez de constructo convergente y divergente mediante el análisis multibrazo-multimétodo, excepto la subescala Actitud, la que presentó valores insatisfactorios. Conclusión: El instrumento presenta resultados satisfactorios de validez y fidedignidad, excluyéndose la dimensión Actitud.

\section{DESCRIPTORES}

Exposición a Agentes Biológicos; Enfermería; Intención; Salud Laboral; Estudios de Validación.

\section{REFERENCES}

1. Magagnini MAM, Rocha AS, Ayres JA. O significado do acidente de trabalho com material biológico para os profissionais de enfermagem. Rev Gaúcha Enferm. 2011;32(2):302-8. DOI: 10.1590/S1983-14472011000200013

2. Valim MD, Marziale MHP, Hayashida M, Richart-Martínez M. Occurrence of occupational accidents involving potentially contaminated biological material among nurses. Acta Paul Enferm. 2014;27(3):280-6. DOI: 10.1590/1982-0194201400047

3. Cavalcante CAA, Cavalcane EFO, Macêdo MLAF, Cavalcante ES, Medeiros SM. Acidentes com material biológico em trabalhadores. Rev Rene. 2013;14(5):971-9.

4. Engin DO, Inan A, Ceran N, Demir ZA, Dagli O, Karagul E, et al. Occupational exposures among healthcare workers: a teaching hospital sample. J Microbiol Infect Dis. 2014;4(2):64-68.

5. Markovic-Denic L, Maksimovic N, Marusic V, Vucicevic J, Ostric I, Djuric D. Occupational exposure among healhcare workers: a teaching hospital sample. Med Princ Pract. 2015; 24(1):36-41. DOI: 10.1159/000368234

6. Marziale MHP, Rocha FLR, Robazzi MLCC, Cenzi CM, Santos HEC, Trovó MEM. Organizational influence on the occurrence of work accidents involving exposure to biological material. Rev Latino Am Enfermagem. 2013;21(n.spe):199-206. DOI: 10.1590/S010411692013000700025

7. Oliveira AC, Paiva MHRS. Analysis of occupational accidents with biological material among professionals in pre-hospital services. Rev Latino Am Enfermagem. 2013;21(1):309-15. DOI: 10.1590/S0104-11692013000100004

8. Paiva MHRS, Oliveira AC. Fatores determinantes e condutas pós-acidente com material biológico entre profissionais do atendimento préhospitalar. Rev Bras Enferm. 2011;64(2):268-73. DOI: 10.1590/S0034-71672011000200008

9. Pimenta FR, Ferreira MD, Gir E, Hayashida M, Canini SRMS. Care and specialized clinical follow-up of nursing professionals who have been victims of accidents with biological material. Rev Esc Enferm USP. 2013;47(1):194-200. DOI: 10.1590/S0080-62342013000100025

10. Amaral PM, Tavares-Neto J. Exposição ocupacional a material biológico por pessoal de saúde: construção e proposição de instrumentos avaliativos. Rev Bras Saúde Ocup. 2010;35(121):131-47. DOI: 10.1590/S0303-76572010000100015

11. Ko NY, Yeh SH, Tsay SL, Ma HJ, Chen CH, Pan SM, et al. Intention to comply with post-exposure management among nurses exposed to blood and body fluids in Taiwan: application of the theory of planned behavior. J Hosp Infect. 2011;77(4):321-6. DOI: 10.1016/j. jhin.2010.09.025

12. Jansen AC, Marziale MHP, Santos CB, Dantas RAS, Ko NY. Assessment of adherence to post-exposure conducts among health workers: translation and cultural adaptation of an instrument. Texto Contexto Enferm. 2015;24(3):670-9. DOI: 10.1590/0104-07072015011010014

13. Laros JA. O uso de análise fatorial: algumas diretrizes para pesquisadores. In: Pasquali L, organizador. Análise fatorial para pesquisadores. Brasília: LabPAM; 2005. p. 163-84.

14. Terwee CB, Bot SD, de Boer MR, van der Windt DA, Knol DL, Dekker J, et al. Quality criteria were proposed for measurement properties of health status questionnaires. J Clin Epidemiol. 2007;60(1):34-42. DOI: 10.1016/j.jclinepi.2006.03.012

15. McDowell I, Newell C. Measuring health: a guide to rating scales and questionnaires. $2^{\text {nd }}$ ed. New York: Oxford U Pr; 1996.

16. Hays RD, Hayashi T, Carson S, Ware JE Jr. User's guide for the Multitrait Analysis Program (MAP) [Internet]. California: Rand Corporation; 1988 [cited 2016 Apr 12]. Available from: https://www.rand.org/content/dam/rand/pubs/notes/2007/N2786.pdf

17. Fayers PM, Machin D. Quality of life: the assessment, analysis and interpretation of patient-reported outcomes. Chichester, England: John Wiley \& Sons; 2007.

18. Conselho Federal de Enfermagem (COFEn); Comissão de Business Intelligence. Produto 2: análise de dados dos profissionais de enfermagem existentes nos Conselhos Regionais [Internet]. Brasília; 2011 [citado 2016 mar. 30]. Disponível em: http://www.cofen.gov.br/wp-content/ uploads/2012/03/pesquisaprofissionais.pdf

19. Beltrame V, Engel R, Comandulli VT, Steffani JA. Cuidado à saúde de quem cuida da saúde. Acidentes ocupacionais com exposição à material biológico ocorridos em municípios da região sul do Brasil e notificados no SINAN nos anos de 2010 a 2012 . Rev Bras Med [Internet]. 2015 [citado 2016 abr. 12];72(8). Disponível em: http://www.moreirajr.com.br/revistas.asp?id_materia=6204\&fase=imprime

20. Santos DMSS, Deon KC, Fegadolli C, Reis RA, Torres LAGMM, Bullinger M, et al. Cultural adaptation and initial psychometric properties of the DISABKIDS ${ }^{\circledR}$ - Cystic Fibrosis Module - Brazilian version. Rev Esc Enferm USP. 2013;47(6):1311-7. DOI: 10.1590/S0080623420130000600009

21. Santos DMSS, Deon KC, Bullinger M, Santos CB. Validity of the DISABKIDS ${ }^{\circledast}$ - Cystic Fibrosis Module for Brazilian children and adolescents. Rev Latino Am Enfermagem. 2014;22(5):819-25. DOI: 10.1590/0104-1169.3450.2485 
22. Schmidt DRC, Dantas RAS. Analysis of validity and reliability of the adapted portuguese version of Antonovsky's Sense of Coherence Questionnaire among nursing professionals. Rev Latino Am Enfermagem. 2011;19(1):42-9. DOI: 10.1590/S0104-11692011000100007

23. Xavier ATF, Foss MC, Marques Junior W, Santos CB, Onofre PTBN, Pace AE. Cultural adaptation and validation of the Neuropathy - and Foot Ulcer - Specific Quality of Life instrument (NeuroQol) for Brazilian Portuguese - Phase 1. Rev Latino Am Enfermagem. 2011;19(6):135261. DOI: $10.1590 /$ S0104-11692011000600011

24. Ajzen I. The theory of planned behaviour: reactions and reflections. Psychol Health. 2011;26(9):1113-27. DOI: 10.1080/08870446.2011.613995

25. Polit DF, Beck CT. Fundamentos de pesquisa em enfermagem: avaliação de evidências para a prática da enfermagem. $7^{\mathrm{a}}$ ed. Porto Alegre: Artmed; 2011.

26. Deon KC, Santos DMSS, Bullinger M, Santos CB. Preliminary psycometric assessment of the Brazilian version of the DISABKIDS ${ }^{\circledR}$ Atopic Dermatitis Module. Rev Saúde Pública. 2011;45(6):1072-8. DOI: 10.1590/S0034-89102011005000067

Financial support: Conselho Nacional de Desenvolvimento Científico e Tecnológico (CNPq). Process 145100/2009-0. 